\title{
Photostats in a College Library
}

$\mathrm{I}^{\mathrm{N}}$ N THE LAST TEN YEARS much more has been published on microfilms and their use in improving and extending library service than on photostats. For certain purposes microfilms are unquestionably superior to photostats. In other instances the reverse is true, and at the two extremes there is almost no controversy as to the relative merits of the two forms of photoduplication. However, between the extremes is an area in which photostats are in competition with microfilms.

There is reason to believe, however, that more attention lately has been given to photostats than may be indicated by the preponderance of publications relating to microfilms. The Iowa State College Library, for example, is finding an increasing number of uses for photostats for which microfilms, although available, have proved to be unacceptable. Furthermore, the library has found that, by installing and operating its own photostat equipment, much better service to the public and to itself is possible than when it was necessary to rely upon outside facilities.

The decision to purchase and operate photostat equipment was not an unconsidered one. Certain urgent needs for photostats in connection with war research projects hastened the inauguration of photostat service, but they were not solely responsible. Other reasons are connected with the recent growth and use of the book collections, particularly in holdings of scientific and technical periodicals.

Partially responsible for the greater use of the library's collections in recent years has been the wider use of journals in the basic sciences. As is commonly realized, hard and fast boundary lines between the sciences no longer exist. Also, research workers in the applied sciences recognize today that they must be thoroughly grounded in certain of the basic sciences. An investigator in dairy industry must not only keep up with the literature of his applied field but also with that of chemistry and bacteriology. Scientific and technical periodicals in chemistry are now used intensively not only by chemists and physicists but by research workers in such applied fields as agronomy, dairy bacteriology, and veterinary pharmacology. As a result, files of journals in the field of chemistry, for example, may be insufficient to meet the demand. The same may be true of the journals in other basic sciences.

The Iowa State College Library's policy concerning loans of scientific and technical periodicals to faculty members has, by tradition, been liberal. However, with increasing demands on the collections, certain revisions in it from time to time have been necessary. The problem has not been one simply of further restricting volumes to use within the library building. What has been needed is a way to make the collections available both in and out of the library and to readers on the campus as well as to persons who are located elsewhere. Extensive duplication by purchase of additional sets, in order to improve and extend library service, was out of the question for obvious reasons. Of all the possible ways of achieving the desired objectives, a photoduplication service in the library seemed to be the most feasible. 


\section{Choosing Photostating}

Once the decision was made to inaugurate a photoduplication service, the next step was to choose between microfilming and photostating. The comparatively large body of literature on the experience of other libraries with microfilms was consulted. As there was a paucity of articles on photostats, however, the writer visited a number of eastern libraries in the spring of 1944 . Some of these institutions employed both microfilming and photostating, although if only one of the two was used it almost invariably was microfilming. In contrast, at the Iowa State College there was a definite preference for photostats.

The Iowa State College Photographic Laboratory-not a part of the library-has offered both microfilm and photostat service for many years. During that period microfilms have, in general, been ordered in lieu of photostats only if the length of the material copied made the latter too costly. By far the greater number of orders from outof-town purchasers have specified photostats, irrespective of actual or relative cost. Faculty members have been extremely vocal on the question. Time after time they have elected to pay the higher prices of photostats. They point out that the microfilm is inconvenient and that reading it causes eyestrain, whereas photostats may be read anywhere and without the aid of any device. The poor quality of some of the microfilms obtained both locally and elsewhere in the past may be partially responsible for the disfavor in which they stand. Sometimes there are perfectly valid reasons for the poor quality of microfilms, but it has been impossible to persuade users of them to appreciate those reasons.

Neither one of the two photostat services now on the campus handicaps the other, for there is ample work for each. Except in emergencies, the library limits its copying to library materials or to volumes borrowed on interlibrary loan. All other types of orders, irrespective of place of origin, are declined. On the other hand, the library does practically all of the photostating of library materials. Such a policy has certain advantages. When pages of irreplaceable items, like expensive architectural folios, war issues of scientific and technical periodicals, or theses, are photostated, there is less likelihood of loss if they do not leave the library. Another advantage is that when the photostating is done by someone trained by the library staff there is less chance that the volumes will be damaged. It is particularly easy for an inexperienced or improperly trained technician to injure book bindings. Other hazards, such as rough handling, and the splattering of chemicals, are minimized by proper care of the volumes as photostated.

\section{Classed as Indispensable}

Although the library's equipment has been in operation about two years, it is already classed as indispensable. Briefly the reasons are: (I) photostats have made it possible for the library to circulate articles in its files of scientific and technical journals more widely and on more liberal terms; (2) photostats at low cost have been used to complete important volumes which lacked pages; (3) graduate students, in studying foreign languages, have used photostats of specialized articles at reduced prices, for the purpose of making practice translations; (4) duplicate copies of materials in the form of photostats have been provided for assigned reading; and (5) special files of photostats of widely scattered information have been assembled in the reference department for the convenience of time-pressed readers.

Under the conditions of great demand now existing the library cannot, without 
seriously impairing service, lend volumes of some of its scientific and technical journals to the faculty for extended periods. Moreover, war issues are rare and should never be lent for use outside of the library building. And even if the original volumes can be spared from the library, there is always the danger, and a very real one when the books are taken to chemical laboratories, that serious damage to them will result. Should the volumes escape chemical hazards, the bindings may not be overlooked by vermin. Also, in the past a number of fires in buildings on the campus have destroyed library publications shelved in offices and laboratories. Many of the volumes which were destroyed can never be replaced except by photographic reproduction. To obviate these difficulties, the library inaugurated a policy of making photostats available at reduced prices. Such an arrangement has proved to be advantageous to both parties to the transaction, since at times it is essential for research workers to have access indefinitely to data published in scientific and technical journals.

There are many objections likewise to sending valuable and much-used journals about the country on interlibrary loan. However, if neither the journals nor copies of them are furnished when needed, important research may suffer. On the basis of requests received from borrowers in this country and Canada, the. Iowa State College Library apparently has certain volumes which are available in few, if any other, libraries in the United States. It is important that the information in such volumes be available to research workers regardless of where they may be located.

Then there is the matter of replacements. For a number of years the library has made a systematic effort to fill in missing pages and even whole numbers of incomplete, damaged, or mutilated volumes with photo- stats when originals were not available. It is now possible, because of savings made possible by library ownership and operation of photostat equipment, to provide fill-ins on a more liberal scale and at reasonable cost to the library.

\section{Photostats for Language Students}

The reading of specialized material by students in learning foreign languages also has entailed a problem. This, done for the sake of familiarity with specialized vocabulary and subject matter, has resulted on several occasions in the ruining of irreplaceable volumes. The forms of injury included ink smears, heavy underlinings in ink, and perspiration stains. The library finally was forced to forbid the unrestricted use of periodicals for this purpose. Extra volumes of certain periodicals in such fields as chemistry, botany, and zoology were then purchased and earmarked for the sole use of students in language courses.

But until photostat service was available in the library no fully satisfactory solution to the problem of supplying material for translation was found. The earmarked collection lacked a sufficiently wide subject variety of material. Now, however, a student who wishes to use a specialized article in any scientific and technical journal may do this provided he secures a photostat copy of the article. He may purchase the photostat copy; or, if he does not wish to do so, the library may assume the expense of photostating and lend him the material. A requirement of the latter arrangement is that the library have a voice in the selection of the pieces. Articles are selected with the aim that they will be useful to others.

\section{Assigned Readings}

The one activity of the library photostat service which is of greatest direct benefit to undergraduates is the making of photostats 
for assigned reading. The original volumes of many of the library's periodicals, especially bound ones, for obvious reasons cannot be placed in the assigned reading room. There they would be subjected to the ruinous handling of classes of students ranging in number from ten to several hundred. Moreover, the limited number of copies of a periodical in the library would be insufficient to fill the demands during rush periods. Many times instructors request library material for assigned reading that is out of print or on such short notice that there is not time to order additional copies. Formerly the alternatives were to purchase photostats at the full commercial price rate or to make typewritten copies. Both methods were inordinately expensive. It is now possible to be more liberal in providing additional photostat copies at no greater total cost to the library. This, in turn, has improved service in the assigned reading room by shortening the time students must wait during rush hours to read their assignments. If necessary, photostat copies can be provided in two hours.

There is a final service which has proved to be a timesaver, for undergraduates especially. Certain assignments, which are repeated annually and in some cases every quarter, involve the search by students for items in widely scattered periodicals. Sometimes the information is difficult to locate. When each student takes the time to assemble and read a few articles, the total expenditure of class time and effort may be out of proportion to the apparent benefit derived. The objectives for the courses referred to apparently do not include training for greater proficiency in using the library. Hence, both reference staff and students are helped if photostats of materials are made and filed at the reference department.

\section{Charges and Costs}

Although a detailed discussion of costs is beyond the scope of this article, the library's position on that topic should be stated. Photostat service to the faculty and students is available at reduced prices. A part of the cost of making such photostats is absorbed by the library in accordance with the general policy applicable to all specialized services, such as translations and interlibrary loans. To do otherwise in the case of photostats would, it is felt, constitute an un-. justifiable exception.

A few items naturally are covered by the charges made to faculty and students for photostats. Anyone may consult price lists of sensitized paper and photographic chemicals to ascertain the cost of those supplies. Add to that figure the cost of labor and utilities-light, power, and water-and the total is what the library considers to be a fair basis for the price of photostats sold to the faculty and students. Other purchasers are required to pay the regular prices in effect at both photostat services.

Two years are too short a period in which to develop the maximum possibilities of the photostat equipment. Enough time has elapsed, however, to show that with library-owned and -operated photostat equipment it is possible (I) to make the library's collections available to more persons and on a more liberal basis; (2) to save the library, the faculty, and students money on photostats of material in the library's collections or of interlibrary loans; and (3) to give better care to the library's collections by making it unnecessary for volumes to be sent out either on interlibrary loan or to be photostated. The above advantages alone would seem amply to justify the purchase and operation of photostat equipment. 